\title{
RPTOR Gene
}

National Cancer Institute

\section{Source}

National Cancer Institute. RPTOR Gene. NCI Thesaurus. Code C104767.

This gene is involved in regulating cell growth. 